\title{
THE EFFECT OF WORKING CAPITAL MANAGEMENT ON PROFITABILITY: EVIDENCE FROM SOUTHEAST EUROPE
}

\author{
Bojana Vukovićl, Dejan Jakšsić ${ }^{2}$ \\ *Corresponding authorE-mail: bojanavuk@ef.uns.ac.rs
}

\begin{abstract}
A R T I C LE IN F O
A B S T R A C T

Review Article

Received: 27 September 2018

Accepted: 15 December 2018

doi:10.5937/ekoPolj1901159V

UDC 657.411.1:338.435(4-12)

Keywords:

Working capital Management, Profitability, Food industry

The research is designed to examine the effect of working capital management on company's profitability in the food industry in Southeast Europe, during the five years period (2010-2014). The sample included 9883 active companies. The influence of certain variables of working capital management (current liquidity, the ratio of current to total assets of companies, the ratio of current liabilities to total assets of companies, financial leverage and size of the company) was measured on the probability of higher profitability by applying probit regression analysis. The results of probit regression provide support to a hypothesis that most of the analyzed variables of working capital management have statistically significant impact on the probability of higher profitability. In this paper is also researched how the optimal level of working capital management can contribute to the growth of profitability and value of the company as a whole.
\end{abstract}

(C) 2019 EA. All rights reserved.

\section{Introduction}

Working capital management is the capital needed to meet the regular, continuous activities of the company and may constitute a high percentage of company's assets. The primary goal of working capital management is to prove a sustainable level of company's current assets and liabilities so that the company does not have the problem with profitability and liquidity. Reduced inventory enhances the financial liquidity risk due to reduced working capital (G olas, Bieniasz, 2016). Except for company's profitability and liquidity, working capital management has the impact on risk, solvency and value. So, efficient working capital management has the impact, not only on profitability as short-term financial performance, but also on shareholder's value maximization, as long-term financial performance.

1 Bojana Vuković Ph.D, Assistant Professor, University of Novi Sad, Faculty of Economics, 9-11 Segedinski put, 24000 Subotica, Serbia; bojanavuk@ef.uns.ac.rs, tel: +381214852933, https://orcid.org/0000-0002-2147-8877

2 Dejan Jakšić Ph.D, Full Professor, University of Novi Sad, Faculty of Economics, 9-11 Segedinski put, 24000 Subotica, Subotica, Serbia; jaksicd@ef.uns.ac.rs, tel:+381214852947, https://orcid.org/0000-0003-1711-1869

http://ea.bg.ac.rs 
In this paper is researched the impact of management of working capital on the profitability of companies in the food industry in 2010-2014. The sample consists of 9883 active companies. The companies in the food industry are chosen according to the fact that this industry has high operational engagement and also high incomes compared to other industries. On the other hand, this industry is characterized by a relatively high rate of indebtedness and loans with extremely high-interest rates and other unfavorable conditions. Another key issue is the problem of insolvency. Further, companies in the food industry in the Southeast Europe has not yet been subject of this kind of research in which was analyzed the impact of working capital management on company's profitability through five components (current liquidity, the ratio of current to total assets, the ratio of current liabilities to total assets, financial leverage and size of the company). Observed countries were Bulgaria, Bosnia and Herzegovina, Greece, Croatia, Romania, Slovenia, Serbia.

The ratio of current liquidity as the ratio of current liabilities and assets represents the company's ability to meet its current liabilities as they mature. Current liquidity is some kind of precondition for ensuring that company is able to meet their shortterm obligations. It is essential to ensure the balance between profitability and liquidity because two main goals of any company are liquidity and profitability. The measurement of profitability and liquidity is vital to the existence and continuous survival of business. It enables companies to have a reasonable idea of their past financial activity (profitability) and current financial position (liquidity), which will provide them to take corrective measures in order to prevent any future financial activity arising from future profitability and liquidity crisis (Chukwunweike, 2014).

The share of current in total assets is a ratio necessary to consider bearing in mind that increasing the share of current assets affects the growth of regular activities. The adequate structure of funding sources is necessary for increased volume of business activities, primarily adequate amount of own and long-term sources. Current liabilities are very important factor in efficient management of working capital, due to the impact on increasing company's profitability and shareholder value (Deloof, 2003). More profitable companies often have lower liabilities.

Leverage is the sum of financial debt that companies use to increase profitability. The higher the level of debt, the higher is leverage, so the greater is the risk of companies. Companies with a lower share of debt, have less leverage and thus lower the risk of bankruptcy and less risk that they will not continue with their continuous activities.

Company's size is an essential determinant of the efficiency of a firm's working capital management. Larger companies may require larger investments in working capital because of larger sales and may be able to use their size because of necessary for reductions in investments in working capital.

Profit is a good measure of the performance of the company. Return on Assets (ROA) is an indicator that showed the efficiency of the company at generating profits from each unit of shareholders equity, in order to explain to what extent does the company use investments in order to earn a profit (Alshatti, 2015). 
In order to determine the impact of management of working capital on profitability, this paper is structured in the following way. Firstly, we revised the relationship between working capital management and profitability through the literature review examined. Secondly, we described data model and used methods to assess the effect of the policy of working capital management on profitability. Before the conclusion, we presented the results of research with the discussion. Based on the results, in the end, we described requirements of the policy of optimal management of working capital, bearing in mind the limitations of the research and plans for future research in this field.

\section{Literature review}

Working capital management is essential in meeting daily activities of any company and often changes its form in the course of daily business of companies. Effective working capital management has a direct impact on profitability and liquidity of the company. According to Harris, A., management of working capital represents the ability of the company to provide adequate coverage of short-term liabilities from short-term assets (Harris, 2005).

Pouraghajan \& Emamgholipourarchi (2012) analyzed the effect of management of working capital on profitability and market valuation of the companies. They analyzed a sample of 400 companies listed in Tehran Stock Exchange in the time period from 2006 to 2010. Return on assets and return on invested capital are observed as a measure of the company's profitability. Cash conversion cycle, current ratio, current to total assets ratio, current liabilities to total assets ratio and total debt to total assets ratio are observed as a measure of management of working capital. The results showed that there exists significant relationship among management of working capital and profitability of the company. Additionally, the results indicated that company's profitability can be improved by reducing cash conversion cycle and the ratio of total liabilities to total assets (Pouraghajan, Emamgholipourarchi, 2012).

Palanisamy, A., Sengottaiyan A. (2015) considered the effect of management of working capital on the profitability. In the focus of research, the author gathered data from pharmaceutical companies in India in the time period from 2002-2004 to 2012-2013. The ratio of total liabilities to capital was negatively linked to return on assets which imply that company should borrow more in order to achieve a higher return on assets. Companies should provide enough cash to fulfill their obligations and ensure high return on their assets. The ratio of current liabilities to total assets was also negatively linked to return on assets, which imply that by increasing current debts, the company will receive a maximum rate of return on assets (Palanisamy, Sengottaiyan, 2015).

The research covered by Irfan Ahmed (2013) examines the impact of management of working capital on the firms' performance by using the financial statement data of 253 non-financial firms listed on Karachi Stock Exchange (KSE). The data were analyzed by Ordinary Least Square (OLS) logistic regression and Pearson's correlation. The result seems that current asset to total sales has a negative relation with profitability, while 
working capital management (WCM) has a positive relation to the firm's performance. However, the logistic result gives the suggestion that firm profitability is highly determined by the current ratio, assets to total asset $\&$ total sales ratio (Ahmed, 2013). Similar research was conducted by Binti, M. \& Mohd Saad, N. in order to analyze the impact of indicators of working capital management on profitability and the company's market value. The results of regression analysis showed that observed indicators such as cash conversion cycle, current liquidity, current assets to total assets ratio, current liabilities to total assets ratio and debt ratio were in an inverse relationship with return on assets and return on invested capital (Binti, Mohd Saad, 2010).

\section{Research methodology}

Proper and optimal management of working capital should ensure that the company has no problems with liquidity and profitability. This paper was considered following indicators of management of working capital: current liquidity, the ratio of current to total assets of companies, the ratio of current liabilities to total assets of companies, financial leverage and size of the company.

The current liquidity ratio represented the company's ability to finance its due liabilities by available current assets. If management increases the level of current in total assets of the company, there will be a more conservative policy in managing current assets of the company. The companies with a lot of current liabilities can face significant liquidity risk, so it is necessary to consider the value of current liabilities to total assets ratio in terms of better financing.

The coefficient of financial leverage presented the share of debt in the total capital of the company ie. how much units of debt come to each unit of capital. A negative sign of financial leverage ratio pointed out that high level of indebtedness due to highinterest rates has reflect on bad operating results and rate of return (Pervan, Mlikota, 2013). Corporate performance is positively linked to capital structure (Soheilirad et al., 2017), so it is very important to take into account the structure of capital in order to have better profitability. Company's size is an essential determinant of the efficiency of management of working capital. Larger companies may require larger investments in working capital because of larger sales.

Return on assets as a measure of profitability explains the ability and performance of a company in using its assets to generate the income. In Table 1 (Table 1.) was presented used indicators of management of working capital and company's profitability.

Table 1. Indicators of Working Capital Management and Profitability

\begin{tabular}{|c|c|}
\hline Indicators & Method of calculation \\
\hline Current liquidity & Current assets/Current liabilities \\
\hline CATAR & Current assets/Total assets \\
\hline CLTAR & Current liabilities/Total assets \\
\hline Debt ratio & Total liabilities/Total capital \\
\hline
\end{tabular}




\begin{tabular}{|c|c|}
\hline Indicators & Method of calculation \\
\hline Return on assets (ROA) & Operating result/Average total assets \\
\hline Size of the company & $\begin{array}{c}\text { According to the number of employees, the amount } \\
\text { of assets and the amount of income }\end{array}$ \\
\hline
\end{tabular}

Source: Author's calculation

\section{Empirical data and analysis}

In order to analyze the relationship between working capital management and profitability, in the paper was used aggregate indicators of financial statements of 9833 active companies. These companies operate in the food industry in the Southeast Europe. Amadeus database was a basis for data because it contains financial and other information of private and public companies (Amadeus, 2017). Probit regression was used in Statistical program Stata 13 as a measurement for the effect of the management of working capital on the possibility of higher profitability of the company. So, return on assets was the dependent variable, while independent variables were current liquidity, the ratio of current to total assets, the ratio of current liabilities to total assets, financial leverage and company's size. According to previous research in this field and bearing in mind the importance of this issue, there were set five hypotheses:

H1: Current liquidity has significant negative impact on the possibility of higher company's profitability.

$\mathrm{H} 2$ : The ratio of current to total assets has significant positive impact on the possibility of higher company's profitability.

$\mathrm{H} 3$ : The ratio of current liabilities to total assets has significant negative impact on the possibility of higher company's profitability.

H4: Financial leverage has significant negative impact on the possibility of higher company's profitability.

H5: Firm's size has significant positive impact on the possibility of higher company's profitability.

\section{Results of the research and discussion}

Descriptive statistics for observed variables was presented in Table 2 (Table 2.). The average rate of profitability in the observed period was $70 \%$, which was in accordance with the reference value $(\geq 10 \%)$. Companies in the food industry had a high level of return on assets of the company. The average value of the ratio of current liquidity was 2.7 , which was in accordance with the reference value $(>2)$. So, short-term assets of companies in the food industry were sufficient for 
settlement short-term liabilities in reporting period. Debts participated in total capital of company 781.3, so the reference value was not satisfied (financial leverage ratio $<1$ ). Companies were indebtedness in observed period and were not financed according to requirements of the traditional theory of finance or theory of organic composition of capital.

Table 2. Descriptive Statistics

\begin{tabular}{|c|c|c|c|c|c|}
\hline Indicators & Obs & $\begin{array}{c}\text { Average } \\
\text { value }\end{array}$ & $\begin{array}{c}\text { Standard } \\
\text { deviation }\end{array}$ & Min & Max \\
\hline Return on Assets & 9883 & .7022178 & .3963243 & $-1.08 \mathrm{e}-06$ & 15.15883 \\
\hline Current Liquidity & 9883 & 2.684623 & 5.889181 & -.5298399 & 99.31111 \\
\hline Current/Total Assets & 9883 & .4625351 & .2477577 & 0 & 1.026116 \\
\hline $\begin{array}{c}\text { Current liabilities/ } \\
\text { Total Assets }\end{array}$ & 9883 & .4192303 & .4940331 & -.0847905 & 10.95211 \\
\hline $\begin{array}{c}\text { Total liabilities/Total } \\
\text { Capital }\end{array}$ & 9883 & 781.3298 & 4315.936 & -.879351 & 85.245 .53 \\
\hline Size & 9883 & .2156228 & .4112745 & 0 & 1 \\
\hline
\end{tabular}

Source: Author's calculation

Table 3 (Table 3.) was presented the results of Chi2 which showed that the model was statistically significant $(\mathrm{p}<0.05)$.

Table 3. Probit regression

\begin{tabular}{|c|c|c|c|}
\hline Log likelihood & LR chi2(5) & Prob > chi2 & Pseudo R2 \\
\hline-6705.7961 & 289.15 & 0.0000 & 0.0211 \\
\hline
\end{tabular}

Source: Author's calculation

According to the results presented in Table 4 (Table 4.), the first three observed variables of working capital management and size of the company significantly affected profitability $(\mathrm{p}<0.05)$. On the other hand, the impact of financial leverage wasn't significant $(\mathrm{p}=0.870)$.

Table 4. Probit regression

\begin{tabular}{|c|c|c|c|c|c|c|}
\hline Indicators & Coef. & Std. Err. & $\mathbf{Z}$ & $\mathbf{P}>|\mathbf{z}|$ & {$[\mathbf{9 5 \%}$ Conf. } & Interval] \\
\hline Current Liquidity & -.0190321 & .0025007 & -7.61 & 0.000 & -.0239334 & -.0141307 \\
\hline Current/Total Assets & .8541686 & .0541317 & 15.78 & 0.000 & .7480724 & .9602648 \\
\hline $\begin{array}{c}\text { Current Liabilities/ } \\
\text { Total Assets }\end{array}$ & -.1350987 & .0288155 & -4.69 & 0.000 & -.191576 & -.0786213 \\
\hline $\begin{array}{c}\text { Total Liabilities/ } \\
\text { Total Capital }\end{array}$ & $-4.85 \mathrm{e}-07$ & $2.97 \mathrm{e}-06$ & -0.16 & 0.870 & $-6.30 \mathrm{e}-06$ & $5.33 \mathrm{e}-06$ \\
\hline Size & .1038481 & .0311709 & 3.33 & 0.001 & .0427543 & .1649419 \\
\hline Cons. & -.309936 & .0291613 & -10.63 & 0.000 & -.3670911 & -.2527809 \\
\hline
\end{tabular}

Source: Author's calculation 
The results of margin effects in Table 5 (Table 5.) showed that current liquidity and ratio of current liabilities to total assets negatively affected the possibility of higher profitability. On the other hand, the ratio of current to total assets and the size of the company positively affected the possibility of higher profitability. These results confirmed hypothesis H1, H2, H3, H5.

Table 5. Margin effects

\begin{tabular}{|c|c|c|c|c|c|c|}
\hline Indicators & $\mathbf{d y} / \mathbf{d x}$ & $\begin{array}{c}\text { Delta- } \\
\mathbf{m e t h o d} \\
\text { Std. Err. }\end{array}$ & $\mathbf{z}$ & $\mathbf{P}>|\mathbf{z}|$ & {$[\mathbf{9 5 \%}$ Conf. } & Interval] \\
\hline Current Liquidity & -.0074198 & .0009667 & -7.68 & 0.000 & -.0093145 & -.005525 \\
\hline Indicators & $\mathbf{d y} / \mathbf{d x}$ & $\begin{array}{c}\text { Delta- } \\
\text { method } \\
\text { Std. Err. }\end{array}$ & $\mathbf{z}$ & $\mathbf{P}>|\mathbf{z}|$ & {$[\mathbf{9 5 \%}$ Conf. } & Interval $]$ \\
\hline Current/Total Assets & .3330029 & .0202707 & 16.43 & 0.000 & .2932731 & .3727328 \\
\hline $\begin{array}{c}\text { Current Liabilities/ } \\
\text { Total Assets }\end{array}$ & -.0526691 & .0111972 & -4.70 & 0.000 & -.0746151 & -.030723 \\
\hline $\begin{array}{c}\text { Total Liabilities/ } \\
\text { Total Capital }\end{array}$ & $-1.89 \mathrm{e}-07$ & $1.16 \mathrm{e}-06$ & -0.16 & 0.870 & $-2.46 \mathrm{e}-06$ & $2.08 \mathrm{e}-06$ \\
\hline Size of the Company & .0405074 & .0121438 & 3.34 & 0.001 & .0167061 & .0643088 \\
\hline
\end{tabular}

Source: Author's calculation

The liquidity issue is time for repaying debts. The significant positive effect of the current assets to total assets ratio on profitability implies that the companies in the food industry in Southeast Europe mostly have a conservative investment policy in working capital. The increase in the value of the current/total assets will lead to the increase in the possibility that ROA will be higher for $0.33 \%$. In addition, the significant negative impact of the current liabilities to total assets ratio on profitability implies less aggressive financing policy in the working capital.

The increase in the value of the size of companies will lead to the increase in the possibility that ROA will be higher for $0.04 \%$. Confirmed the hypothesis H5 was in accordance with research conducted by Ammar et al. (2003) who found that profitability was significantly different among small, medium and large firms because profitability drops as firms grow larger than 50 million dollar sales (Ammar et al., 2003). The reason for higher profitability of the larger firms can be (Pervan, Visic, 2012):

1. the ability of larger firms to cope better with market changes and to determine prices and conditions of the market because of monopoly position;

2. larger firms have greater bargaining power and effectively take advantage of economies of scale and process of research and development;

The empirical research conducted by Akinlo confirmed also that there is a long run steady-state relationship among company's size and profitability. Enhanced company's size can increase company's profitability. As well, enhanced company's profitability can lead to increased company's size (Akinlo, 2012). 
The issue of profitability is a good use of debts. The profitability is affected by the use of debt. During the period of economic expansion, higher financial leverage has a positive impact on business operations, while in the period of economic recession financial leverage has an adverse effect on the profitability of the company. According to the results presented in Table 5 (Table 5.), financial leverage had a negative impact on profitability, but it wasn't significant $(\mathrm{p}=0.870$ ). So, the hypothesis $\mathrm{H} 4$ was disapproved. This result was in accordance with the research conducted by Pepur et al. (2016) who found that profitability is negatively related to leverage, so that the more profitable companies rely more on internal funds, and on this basis there is less need for financing from other sources (Pepur et al., 2016).

Brigham \& Daves agreed that the positive relationship among financial leverage and operating risk is of particular importance for the company's profitability (Brigham, Daves, 2010). Alemeida and Campello discussed that there is a negative relationship between profitability and financing which includes the use of other sources of financing (Alemeida, Campello, 2006). Oppositely, some other schools of thought believes that more profitable firms should rely on external funds like debt to finance their investments (Graham, 2000). Similarly, Papadognas concluded that debt structure and company's size had a positive impact on profitability after analysis of 3035 manufacturing companies in Greece. Regardless of the size of the company, company's profitability is always positively influenced by company's size (Papadognas, 2007). Larger firms are often more profitable, but less productive.

Table 6 (Table 6.) was presented the results of margin effects of current liquidity. The results showed that if current liquidity is 0.5 , the possibility that profitability will be higher is $0.52 \%$. Similarly, if current liquidity is $10,20,100$, the possibility that profitability will be higher is $0.45 \%, 0.37 \%, 0.04 \%$.

Table 6. Margin effects-Current Liquidity

\begin{tabular}{|c|c|c|c|c|c|c|}
\hline Indicators & Margin & $\begin{array}{c}\text { Delta- } \\
\text { method } \\
\text { Std. Err. }\end{array}$ & $\mathbf{z}$ & $\mathbf{P}>|\mathbf{z}|$ & {$[\mathbf{9 5 \%}$ Conf. } & Interval] \\
\hline .5 & .5234124 & .0057899 & 90.40 & 0.000 & .5120645 & .5347604 \\
\hline 2 & .5048771 & .0049912 & 101.15 & 0.000 & .4950945 & .5146598 \\
\hline 10 & .4456899 & .0086377 & 51.60 & 0.000 & .4287603 & .4626195 \\
\hline 20 & .373521 & .0166939 & 22.37 & 0.000 & .3408016 & .4062403 \\
\hline 50 & .1892838 & .0313857 & 6.03 & 0.000 & .1277689 & .2507987 \\
\hline 100 & .0350853 & .0183755 & 1.91 & 0.056 & -.00093 & .0711005 \\
\hline
\end{tabular}

Source: Author's calculation 
Figure 1. Margin effects-Current Liquidity

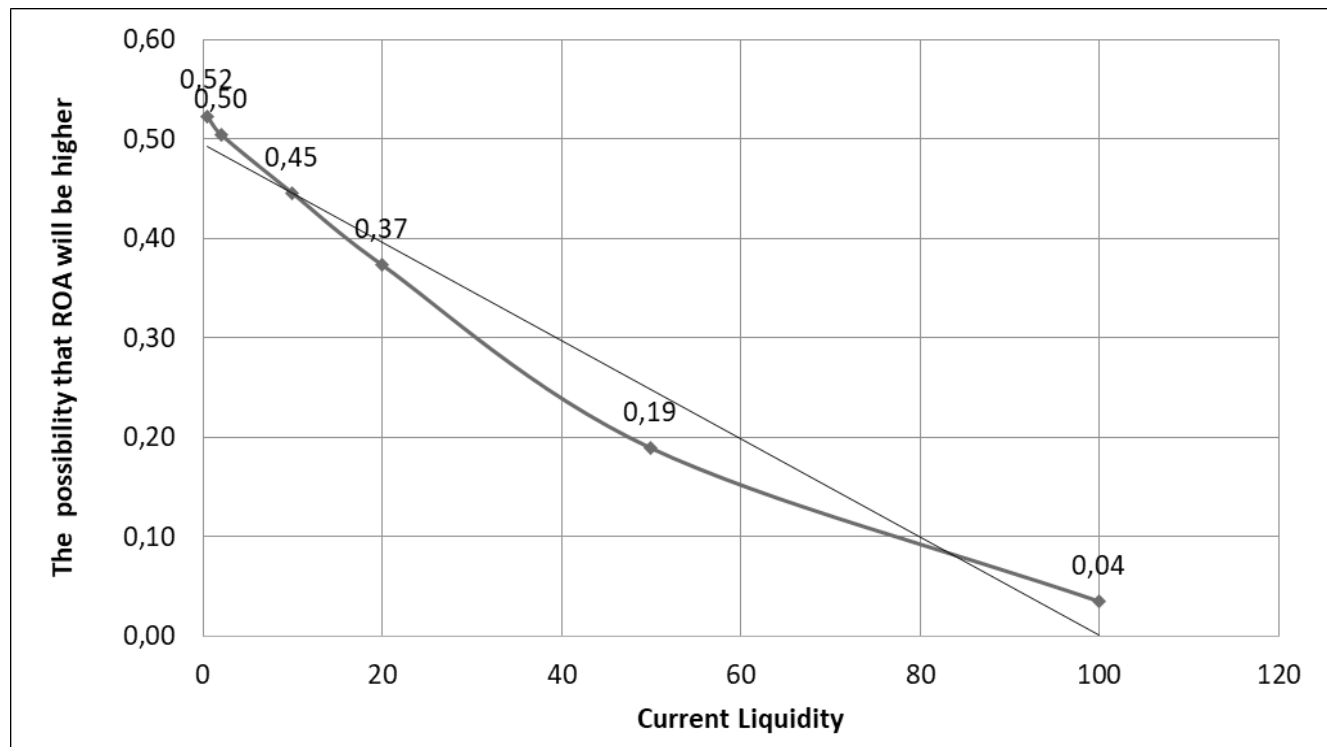

Source: Author's calculation

Table 7 (Table 7.) was presented the results of margin effects of current assets/total assets ratio. The results of margin effects showed that if the ratio of current/total assets is 0.1 , the possibility that profitability will be higher is $0.38 \%$. Similarly, if the ratio of current/total assets is $0.2,0.6,0.8,1$ the possibility that profitability will be higher is $0.41 \%, 0.55 \%, 0.61 \%, 0.68 \%$.

Table 7. Margin effects-Current/Total Assets Ratio

\begin{tabular}{|c|c|c|c|c|c|c|}
\hline Indicators & Margin & $\begin{array}{c}\text { Delta- } \\
\text { method } \\
\text { Std. Err. }\end{array}$ & $\mathbf{z}$ & $\mathbf{P}>|\mathbf{z}|$ & {$[\mathbf{9 5 \%}$ Conf. } & Interval] \\
\hline 0 & .3476561 & .0102652 & 33.87 & 0.000 & .3275366 & .3677755 \\
\hline 0.1 & .3795204 & .0088046 & 43.10 & 0.000 & .3622637 & .396777 \\
\hline 0.2 & .4122191 & .0073448 & 56.12 & 0.000 & .3978235 & .4266147 \\
\hline 0.3 & .4455328 & .0060527 & 73.61 & 0.000 & .4336697 & .4573959 \\
\hline 0.4 & .479229 & .0052021 & 92.12 & 0.000 & .469033 & .4894249 \\
\hline 0.5 & .5130671 & .0051031 & 100.54 & 0.000 & .5030652 & .5230691 \\
\hline 0.6 & .5468038 & .0058004 & 94.27 & 0.000 & .5354353 & .5581723 \\
\hline & Margin & $\begin{array}{c}\text { Delta- } \\
\text { method }\end{array}$ & $\mathbf{z}$ & $\mathbf{P}>|\mathbf{z}|$ & {$[\mathbf{9 5 \%}$ Conf. } & Interval $]$ \\
\hline Std. Err. & & & & .5664521 & .5939434 \\
\hline 0.7 & .5801978 & .0070132 & 82.73 & 0.000 & .56645 \\
\hline 0.8 & .6130155 & .0084441 & 72.60 & 0.000 & .5964654 & .6295656 \\
\hline 0.9 & .6450356 & .0099046 & 65.12 & 0.000 & .6256228 & .6644483 \\
\hline 1 & .6760536 & .011285 & 59.91 & 0.000 & .6539353 & .6981718 \\
\hline
\end{tabular}

Source: Author's calculation 
Table 8 (Table 8.) was presented the results of margin effects of current liabilities/total assets ratio. The results of margin effects showed that if the ratio of current liabilities/ total assets is 1 , the possibility that profitability will be higher is $0.47 \%$. Similarly, if current liabilities/total assets ratio is $2,6,8,10$ the possibility that profitability will be higher is $0.42 \%, 0.23 \%, 0.16 \%, 0.10 \%$.

Table 8. Margin effects-Current Liabilities/Total Assets

\begin{tabular}{|c|c|c|c|c|c|c|}
\hline Indicators & Margin & $\begin{array}{c}\text { Delta- } \\
\text { method } \\
\text { Std. Err. }\end{array}$ & $\mathbf{z}$ & $\mathbf{P}>|\mathbf{z}|$ & {$[\mathbf{9 5 \%}$ Conf. } & Interval] \\
\hline-1 & .5741614 & .0163084 & 35.21 & 0.000 & .5421976 & .6061252 \\
\hline 0 & .5220128 & .006794 & 76.83 & 0.000 & .5086969 & .5353287 \\
\hline 1 & .4694781 & .0081487 & 57.61 & 0.000 & .4535069 & .4854492 \\
\hline 2 & .4174649 & .0179665 & 23.24 & 0.000 & .3822512 & .4526785 \\
\hline 3 & .366854 & .0276361 & 13.27 & 0.000 & .3126882 & .4210198 \\
\hline 4 & .3184553 & .0360948 & 8.82 & 0.000 & .2477108 & .3891998 \\
\hline 5 & .2729685 & .042889 & 6.36 & 0.000 & .1889076 & .3570295 \\
\hline 6 & .2309546 & .0477659 & 4.84 & 0.000 & .1373351 & .324574 \\
\hline 7 & .1928164 & .050634 & 3.81 & 0.000 & .0935755 & .2920573 \\
\hline 8 & .1587927 & .0515477 & 3.08 & 0.002 & .0577611 & .2598243 \\
\hline 9 & .1289623 & .0506846 & 2.54 & 0.011 & .0296223 & .2283024 \\
\hline 10 & .1032591 & .0483165 & 2.14 & 0.033 & .0085605 & .1979577 \\
\hline 11 & .0814935 & .0447743 & 1.82 & 0.069 & -.0062625 & .1692495 \\
\hline
\end{tabular}

Source: Author's calculation

Figure 2. Margin effects-Current Liabilities/Total Assets

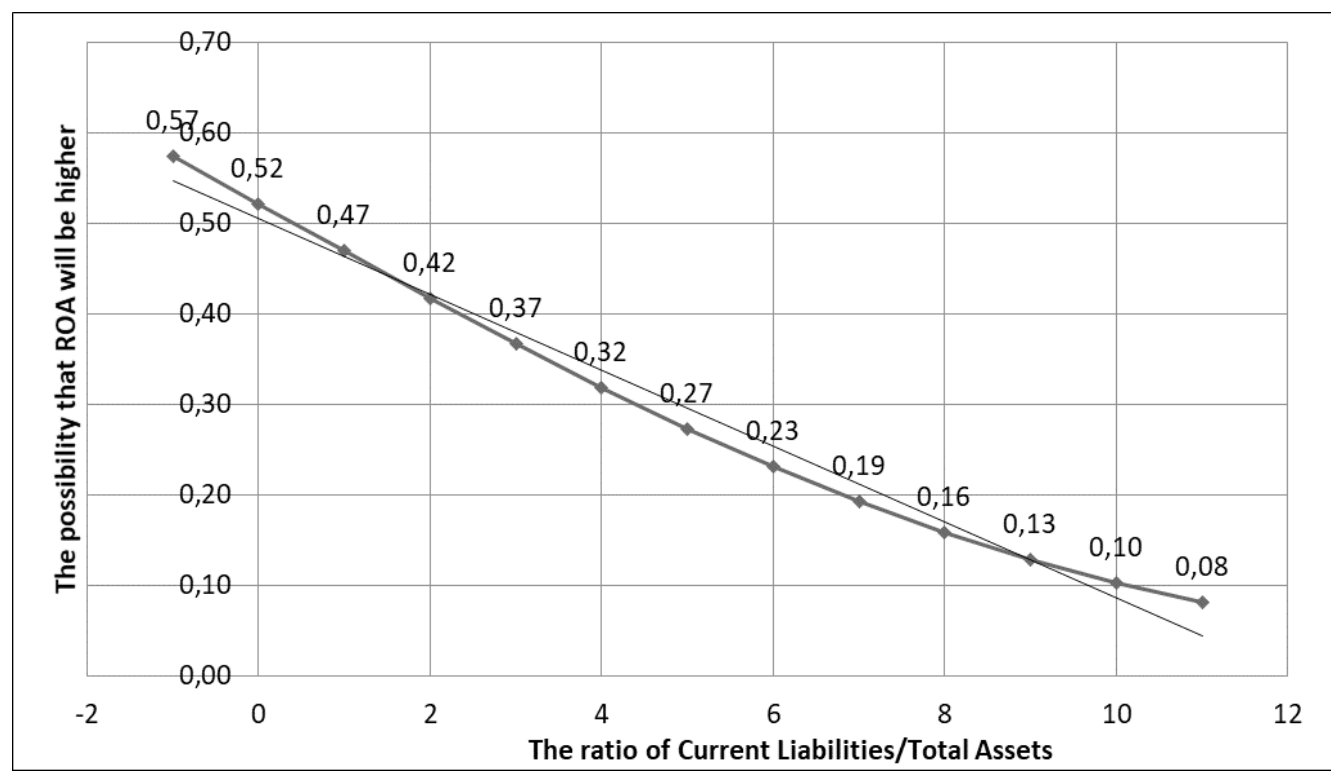

Source: Author's calculation 
Table 9 (Table 9.) was presented the results of margin effects of company size. The results of margin effects showed that if the company size is 0 and 1 , the possibility that profitability will be higher is $0.49 \%$ and $0.53 \%$.

Table 9. Size

\begin{tabular}{|c|c|c|c|c|c|c|}
\hline Indicators & Margin & $\begin{array}{c}\text { Delta- } \\
\text { method } \\
\text { Std. Err. }\end{array}$ & $\mathbf{z}$ & $\mathbf{P}>|\mathbf{z}|$ & {$[\mathbf{9 5 \%}$ Conf. } & Interval $]$ \\
\hline 0 & .49129 & .0056049 & 87.65 & 0.000 & .4803047 & .5022753 \\
\hline 1 & .5317974 & .0107467 & 49.48 & 0.000 & .5107342 & .5528606 \\
\hline
\end{tabular}

Source: Author's calculation

\section{Conclusions}

Achieving an optimal level of management of working capital is a necessary assumption to maintain the going concern principle, regardless of the nature of the company's business. It helps managers to create optimal level between the assets and the liabilities of the company, so whether to invest in current assets as compared to fixed assets or to use more long-term debts as compared to current liabilities.

The results of this research showed that current liquidity and current liabilities to total assets ratio significantly negatively influenced the possibility of higher profitability of companies in the food industry. If the company in the food industry does not have enough cash and cash equivalents that may be the result of large investments. Highest current liability to total asset ratio indicates that the companies need to maintain the higher amount of working capital to maintain its short-term solvency position and automatically reduces the profitability of companies. Companies with a high level of current liabilities in their financing often have a higher market value than the book value. A higher ratio means a relatively aggressive financing policy that yields the negative return on assets.

The larger volume of current assets leads to the growth of profitability of business. If the company opts for an aggressive working capital management policy, it implies a low level of current assets as a percentage of total assets in order to achieve higher gains on fixed assets. More aggressive working capital management is often associated with higher profitability. If firms are having an aggressive approach to managing the short-term liabilities, investors give more value to those firms in stock markets.

Although the impact of financial leverage was not statistically significant, the results confirmed that the leverage is variable which affecting company's profitability negatively. The companies with higher debt rates were less profitable. So, more profitable firms should rely on internal funds in financing their operations. The results also showed that firm's size has significant positive impact on the possibility of higher profitability of the company. So, the absolute firm size plays an important role in explaining profitability.

The effect of working capital management on profitability can be measured using 
different variables and observed many dimensions. In this study, we considered presented five variables, so the study was limited only to the impact of mentioned variables of working capital management on profitability. Some other variables of working capital management as Average Collection Period (Account Receivables), Inventory Turnover in days, Average Payment Period, Cash Conversion Cycle, Net Trading Cycle, Sales Growth and their impact on profitability will be the scope of further research. Profitability would be also measured by Return on Equity (ROE) and Return on Invested Capital (ROIC). There should be also considered some other factors that have an impact on working capital management policies, such as business efficiency, business and economic environment, the technology used, industry affiliation, organizational structure and culture.

Another limitation is data which were available only for 5 years for all seven countries. Data were obtained from financial statements whose truth and objectivity are subject to independent auditors. Bearing in mind that the research was carried out in the food industry, some other industries would be the subject of further studies because the results could vary with the examined industry. Similarly, future research could be conducted in the food industry for some other countries in Europe. According to that, the policy of working capital management could be compared between the countries of Europe in order to determine better guidelines for the company's management and increase the profitability and value of the company in the food industry.

Managers should strive to achieve the higher level of working capital in order to satisfy the growth of production and sales which leads to a greater value of the company in the long run. Efficient management of working capital is especially important for improving cash flow according to the size of the company and to increase company's economic value added. Improving cash flow from efficient working capital management means lower cost of capital and higher value of equity. With the optimal level of working capital, management could utilize profitable investments, promptly and appropriately react to market fluctuations and gain competitive advantages for the companies in the food industry.

\section{Conflict of interests}

The authors declare no conflict of interest.

\section{References}

1. Ahmed, I. (2013). Impact of Working Capital Management on Performance of Listed Non Financial Companies of Pakistan: Application of OLS and LOGIT Models, Proceedings of 2nd International Conference on Business Management, University of Sargodha, Lhore, Punjab, 1-22. Retrieved from: https://www.umt. edu.pk/icobm2012/pdf/2C-55P.pdf

2. Akinlo, E., A. (2012). Firm Size-Profitability Nexus: Evidence from Panel Data for Nigeria. Economic Research-Ekonomska Istraživanja, 25 (3), 706-721. 
3. Alemeida, H., \& Campello, M. (2006). Financial Constraints, Asset Tangibility, and Corporate Investment. NBER Working Papers 12087., National Bureau of Economic Research, 1-37.

4. Alshatti, S. (2015). The Effect of the Liquidity Management on Profitability in the Jordanian Commercial Banks. International Journal of Business and Management, 10 (1), 62-71.

5. Ammar, A., Hanna, A., Nordheim, E., \& Russell, J. (2003). Indicator Variables Model of Firm's Size-Profitability Relationship of Electrical Contractors Using Financial and Economic Data. Journal of Construction Engineering and Management, 129, 192-197.

6. Binti M., N. E. A., \& Mohd Saad, N. B. (2010). Working Capital Management: The Effect of Market Valuation and Profitability in Malaysia. International Journal of Business and Management, 5 (11), 140-155.

7. Brigham, E., \& Daves, P. (2010). Intermediate Financial Management. SouthWestern Cengage Learning, Mason, USA.

8. Chukwunweike, E. (2014). The Impact of Liquidity on Profitability of Some Selected Companies: The Financial Statement Analysis (FSA) Approach. Research Journal of Finance and Accounting, 5 (5), 81-90.

9. Company Information across Europe, Retrieved from https://www.bvdinfo. com/en-us/our-products/company-information/international-products/amadeus (January, 15, 2017)

10. Deloof, M. (2003). Does Working Capital Management Affect Profitability of Belgian Firms? Journal of Business Finance \& Accounting, 30 (3-4), 573-588.

11. Golas, Z., \& Bieniasz, A. (2016). Empirical Analysis of the Influence of Inventory Management on Financial Performance in the Food Industry in Poland. Inzinerine Ekonomika-Engineering Economics, 27 (3), 264-275.

12. Graham, J. (2000). How Big are the Tax Benefits of Debt? Journal of Finance, 55, 1901-1941.

13. Harris, A. (2005). Working Capital Management: Difficult, but Rewarding. Financial Executive, 21 (4), 52-53.

14. Palanisamy, A., \& Sengottaiyan A. (2015). Impact on Profitability of Working Capital Management of Selected Pharmaceutical Companies in India. International Journal of Research in Finance and Marketing, 5 (7), 117-129.

15. Papadogonas, T.A. (2007). The Financial Performance of Large and Small Firms: Evidence from Greece. Int. J. Financial Services Management, 2 (1/2), 1-12.

16. Pepur, S., Ćurak, M., \& Poposki, K. (2016). Corporate Capital Structure: the Case of Large Croatian Companies. Economic Research-Ekonomska Istraživanja, 29, 498-514. 
17. Pervan, M., \& Mlikota, M. (2013). What Determines The Profitability of Companies: Case of Croatian Food and Beverage Industry. Economic ResearchEkonomska istraživanja, 26 (1), 277-286.

18. Pervan, M., \& Visic, J. (2012). Influence of Firm Size on its Business Success. Croatian Operational Research Review, 3, 213-223.

19. Pouraghajan, A., \& Emamgholipourarchi, M. (2012). Impact of Working Capital Management on Profitability and Market Evaluation: Evidence from Tehran Stock Exchange. International Journal of Business and Social Science, 3 (10), 311-318.

20. Soheilirad, S., Sofian, S., Mardani, A., Zavadskas, E., K., Kaklauskas, A., \& Darvishvand, J., M. (2017). The Relationship between Non-Financial Stakeholders and Capital Structure. Inzinerine Ekonomika-Engineering Economics, 28 (4), 363-375. 